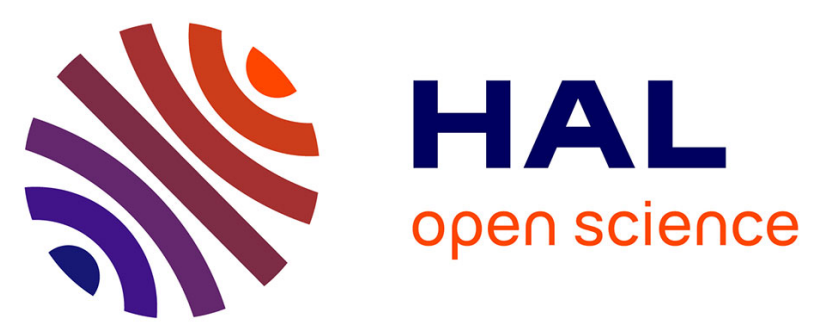

\title{
ATR-FTIR Characterization of Janus Nanoparticles-Part II: Follow-Up Skin Application
}

Kamilia Kemel, Arlette Baillet-Guffroy, Vincent Faivre, Cécile Laugel

\section{To cite this version:}

Kamilia Kemel, Arlette Baillet-Guffroy, Vincent Faivre, Cécile Laugel. ATR-FTIR Characterization of Janus Nanoparticles-Part II: Follow-Up Skin Application. Journal of Pharmaceutical Sciences Elsevier, 2019, 108, pp.3366 - 3371. 10.1016/j.xphs.2019.06.018 . hal-03487637

\section{HAL Id: hal-03487637 https://hal.science/hal-03487637}

Submitted on 21 Dec 2021

HAL is a multi-disciplinary open access archive for the deposit and dissemination of scientific research documents, whether they are published or not. The documents may come from teaching and research institutions in France or abroad, or from public or private research centers.
L'archive ouverte pluridisciplinaire HAL, est destinée au dépôt et à la diffusion de documents scientifiques de niveau recherche, publiés ou non, émanant des établissements d'enseignement et de recherche français ou étrangers, des laboratoires publics ou privés.

\section{다)(1) $(5$}

Distributed under a Creative Commons Attribution - NonCommerciall 4.0 International 


\title{
ATR-FTIR characterization of Janus nanoparticles. Part II: follow-up skin application
}

\author{
Kamilia Kemel, Arlette Baillet-Guffroy, Vincent Faivre, Cécile Laugel.
}

\begin{abstract}
Attenuated total reflection by Fourier transform infrared (ATR-FTIR) was used to implement reliable infrared descriptors over time of Janus nanoparticles (JNP), in order to follow their behavior before and after cutaneous application. In the last study, ATR-FTIR spectroscopic analysis, allowed us to identify the evolution of intensity ratio of $v(\mathrm{C}=\mathrm{O})$ at $1739 \mathrm{~cm}^{-1}$ and $\delta(\mathrm{H}-\mathrm{O}-\mathrm{H})$ at $1639 \mathrm{~cm}^{-1}$ as a spectroscopic descriptor, for JNP before cutaneous application (on the $\mathrm{CaF}_{2}$ window). This descriptor can be used to follow the physical stability (presence) of nanoparticles over time. The purpose of this study is to understand the behavior of JNP on the surface of human skin. Therefore, a comparative study with the untreated skin and the skin after cutaneous application of lipophilic phase (Labrafil) of JNP was conducted using Franz cells. The suitability of the ATR-FTIR descriptor of JNP was evaluated and a research of other descriptors was performed to understand the interaction that may exist between nanoparticles and the skin.
\end{abstract}

Keywords : Janus nanoparticles, Labrafil, skin, cutaneous application, spectroscopic descriptors, ATR-FTIR.

\section{Abbreviations}

ATR-FTIR : attenuated total reflection by Fourier transform infrared spectroscopy JNP : Janus nanoparticles

DLS : dynamic light scattering

Cryo-TEM : cryogenic transmission electron microscopy

PEG : polyethylene glycol

$D_{H}$ : hydrodynamic diameter

Pdi : polydispersity index

$v$ : stretching

$\delta$ : bending

$\mathrm{s}$ : symmetric

as : asymmetric 


\section{Introduction}

Janus nanoparticles (JNP) are the dispersion of objects characterized by the presence of a lipid compartment associated with an aqueous compartment delimited by a phospholipid bilayer. The size of JNP varies between 150 and $300 \mathrm{~nm} \cdot{ }^{1,2} \mathrm{JNP}$ are very promising tools, the encapsulation of two active pharmaceutical ingredients of opposite chemical polarity for the same nanoformulation can be consider. So, they are interesting in the drug delivery and in cosmetic domains. Then, JNP seems to be good candidates for cutaneous application.

The technique of dynamic light scattering (DLS) measures the size distribution of JNP. The cryogenic transmission electron microscopy (cryo-TEM) enables to visualize the coexistence of the two opposite compartments of JNP. ${ }^{3}$ These two methods cannot be used to study vehicle-skin interactions, if we want to understand the behavior of JNP after cutaneous application. Therefore, a technique that is rapid and non-invasive for the system studied is required. Thus, ATR-FTIR method is a very informative analytical tool facilitates to produce the direct analysis of the surface of a sample contacting the ATR crystal. It has been shown that it is suitable for the study of cutaneous tissue. ${ }^{4}$ Therefore, ATR-FTIR was used to implement reliable infrared descriptors over time of JNP before and after cutaneous application.

In the last study, the experiments were conducted in an air-conditioned chamber at $22^{\circ} \mathrm{C}$. Kinetics were performed in triplicate for JNP. One drop of $25 \mu \mathrm{L}$ was deposited on the $\mathrm{CaF}_{2}$ window. They were held over 4 hours with spectral measurements every 10 min. A comparative study with a nanoemulsion (NE) and a physical mixture (PM) formulation was conducted. The same JNP formulation method was used for the formulation of NE but without incorporation of phospholipids. PM is unstable dispersion of the same qualitative and quantitative composition as the dispersion of JNP. ATR-FTIR spectroscopic analysis allowed to identify the evolution of intensity ratio of $v(C=O)$ at 1739 $\mathrm{cm}^{-1}$ and $\delta(\mathrm{H}-\mathrm{O}-\mathrm{H})$ at $1639 \mathrm{~cm}^{-1}$ as a spectroscopic descriptor for JNP. This descriptor can be used to follow the physical stability (presence) of nanoparticles over time. The results of infrared spectroscopy were confirmed by measurements of size distribution of JNP and validated by chemometric tools. ${ }^{5}$

In the present study, ATR-FTIR was used to follow the behavior of JNP after cutaneous application. Using Franz cells and human skin biopsies, three kinetics were carried out for untreated skin, biopsies with JNP and biopsies with Labrafil $2125 \mathrm{CS}^{\circledR}$. The Labrafil represents the lipophilic phase of JNP, and it is the major compound after water. The kinetics of Labrafil was conducted to evaluate the difference of behavior between Labrafil alone and Labrafil contained in JNP. The suitability of the ATR-FTIR descriptor of JNP was evaluated and a search for other descriptors was performed. 


\section{Materials and Methods}

\subsection{Materials}

Gelucire $50 / 13^{\circledR}$ (a mixture of mono-, di- and triacylglycerols of palmitic and stearic acid (20\%), monoand di-esters of PEG (Polyethylene glycol) 1500 ( 70\% with a majority of di-esters) and free PEG $1500(\sim 8 \%)$ ) and Labrafil M2125 CS ${ }^{\circledR}$ (a mixture of mono-, di- and triglycerides of linoleic acid and mono- and diesters of PEG 300 (55\% glycerides, 45\% PEG ester)) were obtained from Gattefossé (Saint-Priest, France). Phospholipon $90 \mathrm{G}^{\circledR}$ (purified phospholipid mixture obtained from soybean lecithin consisting primarily of phosphatidylcholine (94-102\%), lysophosphatidylcholine $(\leq 4 \%)$ and tocopherol) was synthesized by Lipoid (Köln, Germany). Water was purified with the Milli-Q water system (Millipore, France). Bovine serum albumin was purchased at Sigma-Aldrich (Saint-Quentin Fallavier, France). Sodium chloride salts was purchased at Carlo Erba Réactifs-Sds (Val de Reuil, France).

\subsection{Methods}

\subsubsection{Preparation of Janus nanoparticles}

The aqueous phase consisted of $2 \%(\mathrm{w} / \mathrm{w})$ Gelucire 50/13 ${ }^{\circledR}, 1 \%(\mathrm{w} / \mathrm{w})$ Phospholipon $90 \mathrm{G}^{\circledR}$ and $77 \%$ $(\mathrm{w} / \mathrm{w})$ Milli-Q water and the lipophilic phase was $20 \%(\mathrm{w} / \mathrm{w})$ Labrafil M2125CS ${ }^{\circledR}$. The mixture of Gelucire 50/13 ${ }^{\circledR} /$ Phospholipon $90 \mathrm{G}^{\circledR}$ was dispersed in Milli-Q water and heated in a $70^{\circ} \mathrm{C}$ water bath for 5 min with mechanic stirring. The oil phase, consisting of Labrafil $M 2125 \mathrm{CS}^{\circledR}$, was also heated at the same temperature. The oil phase was added dropwise in the aqueous phase and the mixture was stirred with an Ultra-Turrax T18 (Janke \& Kunkel GMBH \& Co.KG, IKA®-Labotechnik, Germany) at $7,000 \mathrm{rpm}$ (rotations per minute). Rotor speed was then increased to $11,000 \mathrm{rpm}$ for $5 \mathrm{~min}$. In order to reduce and standardize the size of the particles, the dispersion was passed through a high-pressure homogenizer (APV-2000) at pressures of 600 and 200 bar for the first and second stages, for 5 min at $70^{\circ} \mathrm{C}$. The final product was a whitish dispersion of nanoparticles in water.

\subsubsection{DLS: Measuring the size distribution of Janus nanoparticles}

The hydrodynamic diameter and the polydispersity index were measured with a Zetasizer Nano ZS90 (Malvern Instruments, Orsay, France), piloted by Zetasizer Software. The Zetasizer Nano ZS90 detector was positioned at $90^{\circ}$ to the sample and the attenuation was determined automatically by the Nanosizer during the measurement sequence. The measurement cell contained $1.5 \mathrm{~mL}$ of water to which was added $5 \mu \mathrm{L}$ of the dispersion of the nanoparticles (a 1/300 dilution) and the cell contents were homogenized. Each sample was analyzed in triplicate at controlled temperature $\left(25^{\circ} \mathrm{C}\right)$. The mean hydrodynamic diameter $\left(\mathrm{D}_{\mathrm{H}}\right)$ of the produced batch was $222 \pm 66 \mathrm{~nm}$ and the polydispersity index (Pdi) was $0.069 \pm 0.025$.

\subsubsection{Ex vivo skin penetration study}

Ex vivo skin penetration of JNP was studied using Franz cells (Lara Spirals, Couternon, France) with a diffusion area of $1.54 \mathrm{~cm}^{2}$ and a volume $4 \mathrm{~mL}$ of receptor chamber. Human skin was obtained from abdominal plastic surgery of healthy women, stored at $-25^{\circ} \mathrm{C}$. Left in the open air before experiments 
the skin was defrosted and the subcutaneous fatty tissue was removed from the skin using a scalpel. Cleaned with Millipore $Q$ water and dried with paper, the skin was cut into circle shapes to fit the glass diffusion cells. The human skin was mounted between donor and receptor compartment of Franz cell, avoiding bubbles formation with a receptor liquid containing $0.85 \%$ of saline serum, $0.01 \%$ of bovine serum albumin and Millipore $Q$ water. In order to mimic the physiological conditions, the Franz cells were kept in a thermostated water bath at $37^{\circ} \mathrm{C}$, to maintain the skin surface temperature at $32^{\circ} \mathrm{C}$, with a permanent magnetic stirring of the receptor liquid. After $30 \mathrm{~min}$ of stabilization, $25 \mu \mathrm{L}$ of the dispersion of JNP or $25 \mu \mathrm{L}$ of Labrafil $2125 \mathrm{CS}^{\circledR}$ were deposited on the surface of the skin. An untreated skin (without application of any formulation) was performed.

Three kinetics were carried out for the untreated skin, biopsies with JNP, assigned skin+JNP and biopsies with Labrafil $2125 \mathrm{CS}^{\circledR}$, assigned skin+L. Kinetics were held over 24 hours with several measurement times. Experiments were performed in triplicate.

At each time, the donor compartment was removed, and the skin biopsy was examined by ATR-FTIR.

\subsubsection{Infrared vibrational spectroscopy: ATR-FTIR spectra recording}

The infrared spectrophotometer used for the study was ATR-FTIR Spectrum two from PerkinElmer (Waltham, Massachusetts) piloted by PerkinElmer Spectrum software (version 10.4.2.279). The spectral range used was $450-4000 \mathrm{~cm}^{-1}$ with resolution of $4 \mathrm{~cm}^{-1}$ and 16 scans were acquired by run. The background of the ATR-FTIR spectrophotometer was air.

Each skin biopsy was deposited on the crystal ATR and a spectrum was recorded on the surface of the sample. The only pre-treatment which was performed for the spectra was baseline correction. 


\section{Results and discussion}

\subsection{Band assignments of skin, JNP and L}

The spectral signature of skin (SC), JNP and L are shown in figure 1.

The main vibration bands of the SC are: (I) $3400-3200 \mathrm{~cm}^{-1}$ assigned to $v(\mathrm{O}-\mathrm{H})$ of water and $v(\mathrm{~N}-\mathrm{H})$ of ceramides; (II) $2920 \mathrm{~cm}^{-1}$ and $2850 \mathrm{~cm}^{-1}$ assigned to the $v_{a s}\left(\mathrm{CH}_{2}\right)$ and $v_{s}\left(\mathrm{CH}_{2}\right)$ of aliphatic $\mathrm{CH}_{2}$ group of lipids; (III) $1742 \mathrm{~cm}^{-1}$ assigned to the $v\left(\mathrm{C}=\mathrm{O}\right.$ ) of the fatty acids; (IV) $1645 \mathrm{~cm}^{-1}$ assigned to the $v\left(\mathrm{C}=\mathrm{O}\right.$ ) of the keratin (amide I); (V) $1545 \mathrm{~cm}^{-1}$ assigned to the $\delta(\mathrm{N}-\mathrm{H})$ and $v(\mathrm{C}-\mathrm{N})$ of ceramide (amide II). ${ }^{6,7}$ (Figure 1a)

The main vibration bands of JNP are: (I) $3500-3150 \mathrm{~cm}^{-1}$ assigned to the $v(\mathrm{O}-\mathrm{H})$ of water; (II) $2926 \mathrm{~cm}^{-}$ 1 and $2853 \mathrm{~cm}^{-1}$ assigned to the $v_{a s}\left(\mathrm{CH}_{2}\right)$ and $v_{s}\left(\mathrm{CH}_{2}\right)$ of aliphatic $\mathrm{CH}_{2}$ group of lipids; (III) $1739 \mathrm{~cm}^{-1}$ assigned to the $v(\mathrm{C}=\mathrm{O})$ of the ester carbonyl functional groups of the glycerides and PEG 300 esters of the Labrafil; and (IV) $1639 \mathrm{~cm}^{-1}$ assigned to the $\delta\left(\mathrm{H}-\mathrm{O}-\mathrm{H}\right.$ ) of water. ${ }^{5,8-11}$ (Figure $1 \mathrm{~b}$ )

The main vibration bands of $\mathrm{L}$ are: (I) $3474 \mathrm{~cm}^{-1}$ assigned to the $v(\mathrm{O}-\mathrm{H})$ of mono and diglycerides; (II) the $2923 \mathrm{~cm}^{-1}$ and $2853 \mathrm{~cm}^{-1}$ assigned to the $v_{a s}\left(\mathrm{CH}_{2}\right)$ and $v_{s}\left(\mathrm{CH}_{2}\right)$ of aliphatic $\mathrm{CH}_{2}$ group of lipids; (III) $1739 \mathrm{~cm}^{-1}$ assigned to the $v(\mathrm{C}=\mathrm{O})$ of the ester carbonyl functional groups of the glycerides and $\mathrm{PEG}$ 300 esters, (IV) $1655 \mathrm{~cm}^{-1}$ assigned to the $v(\mathrm{C}=\mathrm{C})$ of glycerides; (V) $1180-1110 \mathrm{~cm}^{-1}$ assigned to the $v(\mathrm{C}-\mathrm{O})$ and $v(\mathrm{C}-\mathrm{C})$ of the glycerides and esters of PEG $300 .{ }^{9-12}$ (Figure 1C)

The vibration bands presented above represent interest and susceptible bands to be modified during the present study, for the skin it is the principal bands most often studied.

\subsection{Ex vivo skin penetration study: untreated skin, Skin+JNP and Skin+L}

The kinetics performed on untreated skin showed that the spectral signature of skin did not vary over time (Data not shown).

The kinetics of skin+JNP are shown in figure 2a. At toh, after cutaneous application of JNP, the spectral signature of the skin disappeared, consequently the infrared spectrum of JNP was observed. As function of time, the spectra exhibited variations of the intensity of vibration bands. The $v(\mathrm{O}-\mathrm{H})$ from 3150 to $3500 \mathrm{~cm}^{-1}$ and $\delta(\mathrm{H}-\mathrm{O}-\mathrm{H})$ at $1639 \mathrm{~cm}^{-1}$ of water decreased, giving a direct reflection of water evaporation. The $v_{a s}\left(\mathrm{CH}_{2}\right)$ at $2926 \mathrm{~cm}^{-1}, v_{s}\left(\mathrm{CH}_{2}\right)$ at $2853 \mathrm{~cm}^{-1}, v(\mathrm{C}=\mathrm{O})$ at $1739 \mathrm{~cm}^{-1}$ and $v(\mathrm{C}-\mathrm{O})$ from 1110 to $1180 \mathrm{~cm}^{-1}$ of Labrafil (major compound after water) increased as result of the increasing concentration of the oil. JNP on skin exhibited the same evolution of spectra as observed of JNP deposited on the $\mathrm{CaF}_{2}$ window.

The kinetics of skin $+L$ is shown in figure $2 b$. At ton, after cutaneous application of $L$, the spectral signature of the skin disappeared, and the infrared spectrum of $L$ was observed. The spectra did not exhibit any variations over time.

The evolution of intensity ratio of $v(\mathrm{C}=\mathrm{O})$ at $1739 \mathrm{~cm}^{-1}$ and $\delta(\mathrm{H}-\mathrm{O}-\mathrm{H})$ at $1639 \mathrm{~cm}^{-1}$, was identified as a spectroscopic descriptor for JNP. It allowed to follow the behavior of JNP in vitro (on the $\mathrm{CaF}_{2}$ window) ${ }^{5}$. To follow the behavior of JNP on the surface of skin, the suitability of the ATR-FTIR descriptor of JNP was assessed. The spectrum of skin has vibration bands in the same spectral region 
as the descriptor of $\mathrm{JNP}$, the $v(\mathrm{C}=\mathrm{O})$ at $1742 \mathrm{~cm}^{-1}$ of lipids and another $v(\mathrm{C}=\mathrm{O})$ of the keratin at 1645 $\mathrm{cm}^{-1}$. The intensity ratio of $1742 \mathrm{~cm}^{-1}$ and $1645 \mathrm{~cm}^{-1}$ was calculated for untreated skin, its value was very low (around 0.15 ) and did not change over time (Figure 3). So, the contribution of the signal from skin was not significant on the variation of the descriptor after the application of nanoparticles. The ATR-FTIR descriptor identified in vitro for the nanoparticles was therefore also validated for this study. Then, the ratio $\frac{\mathrm{I}_{v(\mathrm{C}=\mathrm{O})}}{\mathrm{I}_{\delta(\mathrm{O}-\mathrm{H})}}$ was calculated at each time for skin+JNP, the evolution of this ratio with time is shown in figure 3.

At first, an increase of the ratio was observed from to $\mathrm{h}$ to $\mathrm{t}_{1} \mathrm{~h}$ for JNP and skin+JNP. In this range time range, JNP were mostly intact with an appearance of whitish liquid formulation (macroscopic observations). Skin+JNP varied with a slightly higher slope than JNP in vitro. Because JNP were on the surface of the skin, they were found in a micro-environment different from that of the $\mathrm{CaF}_{2}$ window. Contrary to the $\mathrm{CaF}_{2}$ window, which is an inert support, the nanoparticles on the surface of the skin were found in a biological environment. Firstly, the skin biopsies were maintained in the hydrated state thanks to the receptor liquid. Secondly, the surface temperature of the skin was at $32^{\circ} \mathrm{C}$ and the surface of the $\mathrm{CaF}_{2}$ window at $22^{\circ} \mathrm{C}$. Indeed, the physical degradation of JNP are dependent on this second parameter (temperature). It has been observed that the nanoparticles are less fragile at $22^{\circ} \mathrm{C}$ compared to $32^{\circ} \mathrm{C}$ (Figure 4). So, the physical degradation of JNP is slower on the $\mathrm{CaF}_{2}$ window compared to JNP on the surface of skin.

Then, a change marked by a slope was detected from $t_{1} h$ to $t_{3} h$ for JNP and skin+JNP, with the progressive physical degradation of the JNP. This increase was less important for skin+JNP compared to JNP in vitro for which an important slope appears. This showed a loss of quantity of JNP after the cutaneous application and therefore a penetration of the formulation.

Finally, for JNP on the $\mathrm{CaF}_{2}$ window, a plateau was reached to the value 45. In this case, JNP were mostly degraded with an appearance of a transparent viscous formulation (macroscopic observations). For JNP on the surface of skin, a second change of slope was detected with decrease of the ratio from $t_{3} \mathrm{~h}$ to $t_{6} \mathrm{~h}$. This showed a significant loss of quantity of JNP and therefore a penetration more important of the formulation. Afterwards a plateau was reached to the value 5. The different plateau values of the descriptor confirmed the cutaneous penetration of JNP.

In addition to the descriptor, we examined the variations of $v(\mathrm{C}=\mathrm{O})$ of lipids and $\delta(\mathrm{O}-\mathrm{H})$ of water before and after cutaneous application of JNP. We also compared them to the results obtained with untreated skin and skin+L.

The elongation of $\mathrm{C}=\mathrm{O}$ of the lipids was around $1745 \mathrm{~cm}^{-1}$ for skin, at $1739 \mathrm{~cm}^{-1}$ for JNP and L. Over time it did not change for untreated skin. For JNP, skin+JNP and skin $+\mathrm{L}$, the elongation of $\mathrm{C}=\mathrm{O}$ was around $1739 \mathrm{~cm}^{-1}$, and did not shift over time. The $1739 \mathrm{~cm}^{-1}$ is characteristic to $\mathrm{L}$ alone or in JNP. This indicated, after $24 \mathrm{~h}$, the Labrafil was still present on the surface of the skin after cutaneous application of JNP and L. (Figure 5) 
For JNP (in vitro), over time the deformation of O-H of water at $1639 \mathrm{~cm}^{-1}$ shifted to the elongation of $\mathrm{C}=\mathrm{C}$ of glycerides $v(\mathrm{C}=\mathrm{C})$ at $1654 \mathrm{~cm}^{-1}$. This is due to the increasing of the oil concentration, as a result of water evaporation.

For untreated skin, the elongation of $\mathrm{C}=\mathrm{O}$ of the keratin at $1645 \mathrm{~cm}^{-1}$ did not vary. Also, for skin $+\mathrm{L}$, the elongation of $\mathrm{C}=\mathrm{C}$ of glycerides at $1652 \mathrm{~cm}^{-1}$ did not shift.

For skin+JNP, from to $\mathrm{h}$ to $\mathrm{t}_{1.5 \mathrm{~h}} \mathrm{~h}$, the deformation of $\mathrm{O}-\mathrm{H}$ of water $\delta(\mathrm{O}-\mathrm{H})$ at $1639 \mathrm{~cm}^{-1}$ shifted to the elongation of $\mathrm{C}=\mathrm{C}$ of glycerides $v\left(\mathrm{C}=\mathrm{C}\right.$ ) at $1650 \mathrm{~cm}^{-1}$, as JNP (in vitro). After $\mathrm{t} 1.5 \mathrm{~h}$, the value stabilized around $1650 \mathrm{~cm}^{-1}$. This indicated again the presence of Labrafil on the surface of skin. (Figure 6)

\section{Conclusion}

The cutaneous application of JNP showed the same evolution of spectra as observed of JNP deposited on the $\mathrm{CaF}_{2}$ window. Over time, the $v(\mathrm{O}-\mathrm{H})$ from 3150 to $3500 \mathrm{~cm}^{-1}$ and $\delta(\mathrm{O}-\mathrm{H})$ at $1639 \mathrm{~cm}^{-1}$ of water decreased. The $v_{a s}\left(\mathrm{CH}_{2}\right)$ at $2926 \mathrm{~cm}^{-1}, v_{s}\left(\mathrm{CH}_{2}\right)$ at $2853 \mathrm{~cm}^{-1}, v(\mathrm{C}=\mathrm{O})$ at $1739 \mathrm{~cm}^{-1}$ and $v(\mathrm{C}-\mathrm{O})$ from 1110 to $1180 \mathrm{~cm}^{-1}$ of Labrafil $\mathrm{M}_{2} 125 \mathrm{CS}^{\circledR}$ increased, as a result the progressive physical degradation of JNP.

Over time, the evolution of intensity ratio of $v(\mathrm{C}=\mathrm{O})$ at $1739 \mathrm{~cm}^{-1}$ and $\delta(\mathrm{O}-\mathrm{H})$ at $1639 \mathrm{~cm}^{-1}$ was validated as descriptor of JNP before cutaneous application (on the $\mathrm{CaF}_{2}$ window). To follow their behavior over time, the suitability of the ATR-FTIR descriptor of JNP on the surface of the skin was assessed. So, the contribution of the signal from skin was not significant. Therefore, the IR descriptor was also appropriate to follow the behavior of JNP on the surface of human skin.

Thus, the ratio $\frac{\mathrm{I} v(\mathrm{C}=\mathrm{O})}{\mathrm{I}_{\delta(\mathrm{O}-\mathrm{H})}}$ was calculated to study the evolution of JNP over time. From to $\mathrm{h}$ to $\mathrm{t}_{1} \mathrm{~h}$, JNP were mostly intact. Compared to JNP on the $\mathrm{CaF}_{2}$ window the physical degradation was slightly higher of JNP on the surface of skin, as JNP were sensible to the temperature of the skin. Unlike JNP on $\mathrm{CaF}_{2}$ window, from $t_{1} \mathrm{~h}$ to $t_{3} \mathrm{~h}$, the ratio of JNP on the surface of skin increased more slowly. This showed the progressive physical degradation of the JNP and a loss of quantity of JNP. Therefore, the penetration of the formulation had begun. From $t_{3} \mathrm{~h}$ to $t_{6}$, the ratio decreased and then showed $a$ significant loss of quantity. So, the penetration of the formulation was more important than the last time interval. Afterwards a plateau was reached to a value much lower than the value of the plateau obtained with JNP on CaF2 window. This observation confirmed the cutaneous penetration of JNP.

The inspection of the variations of $v(\mathrm{C}=\mathrm{O})$ of lipids and $\delta(\mathrm{O}-\mathrm{H})$ of water after cutaneous application of JNP, revealed that the Labrafil was still present on the surface of the skin after $24 \mathrm{~h}$.

The kinetics of Labrafil (lipophilic phase of JNP) was conducted to evaluate the difference of behavior between Labrafil alone and Labrafil contained in JNP. The recorded spectra after cutaneous application of Labrafil, did not showed any variations over time. Then, the Labrafil alone did not penetrate in the skin. In contrast, when Labrafil was contained in JNP, a disappearance of the formulation was observed. Therefore, the skin penetration of JNP did occur. 


\section{References}

1. Tran, L.-T.-C., Lesieur, S. \& Faivre, V. Janus nanoparticles: materials, preparation and recent advances in drug delivery. Expert Opin Drug Deliv 11, 1061-1074 (2014).

2. Truong-Cong, T. et al. A scalable process to produce lipid-based compartmented Janus nanoparticles with pharmaceutically approved excipients. Nanoscale (2018). doi:10.1039/C7NR08488A

3. Song, Y. \& Chen, S. Janus Nanoparticles: Preparation, Characterization, and Applications. Chem. Asian J. 9, 418-430 (2014).

4. Corbe, E., Laugel, C., Yagoubi, N. \& Baillet, A. Role of ceramide structure and its microenvironment on the conformational order of model stratum corneum lipids mixtures: an approach by FTIR spectroscopy. Chem. Phys. Lipids 146, 67-75 (2007).

5. Kemel, K. et al. ATR-FTIR Characterization of Janus Nanoparticles. Part I: Implementation of Spectroscopic Descriptors. Journal of Pharmaceutical Sciences (2018). doi:10.1016/j.xphs.2018.04.022

6. Machado, M., Hadgraft, J. \& Lane, M. E. Assessment of the variation of skin barrier function with anatomic site, age, gender and ethnicity. Int J Cosmet Sci 32, 397-409 (2010).

7. Olsztyńska-Janus, S., Pietruszka, A., Kiełbowicz, Z. \& Czarnecki, M. A. ATR-IR study of skin components: Lipids, proteins and water. Part I: Temperature effect. Spectrochim Acta A Mol Biomol Spectrosc 188, 37-49 (2018).

8. Mojet, B. L., Ebbesen, S. D. \& Lefferts, L. Light at the interface: the potential of attenuated total reflection infrared spectroscopy for understanding heterogeneous catalysis in water. Chem Soc Rev 39, 4643-4655 (2010).

9. Gomez, N. A., Abonia, R., Cadavid, H. \& Vargas, I. H. Chemical and spectroscopic characterization of a vegetable oil used as dielectric coolant in distribution transformers. Journal of the Brazilian Chemical Society 22, 2292-2303 (2011).

10. Alexa, E. et al. The use of FT-IR spectroscopy in the identification of vegetable oils adulteration. Journal of Food Agriculture and Environment 7, (2009).

11. Poiana, M.-A. et al. Use of ATR-FTIR spectroscopy to detect the changes in extra virgin olive oil by adulteration with soybean oil and high temperature heat treatment. Open Chemistry 13, (2015).

12. Guillén, M. D. \& Cabo, N. Characterization of edible oils and lard by fourier transform infrared spectroscopy. Relationships between composition and frequency of concrete bands in the fingerprint region. J Amer Oil Chem Soc 74, 1281-1286 (1997). 


\section{Legends}

Figure 1 : ATR-FTIR spectra of untreated skin (a), JNP (b) and L (c)

Figure 2 : Kinetic changes of ATR-FTIR spectra; skin+JNP (a) and skin+L (b) versus time, from $0 \mathrm{~h}$ to $24 \mathrm{~h}$.

i: the intensity of $v(\mathrm{O}-\mathrm{H})$ from 3150 to $3500 \mathrm{~cm}^{-1}$ decreased over time.

ii: the intensity of $v(\mathrm{C}=\mathrm{O})$ at $1739 \mathrm{~cm}^{-1}$ increased and the intensity $\delta(\mathrm{O}-\mathrm{H})$ at $1639 \mathrm{~cm}^{-1}$ decreased over time.

Figure 3 : Evolution of intensity ratios of $v(\mathrm{C}=\mathrm{O})\left(1739 \mathrm{~cm}^{-1}\right)$ and $\delta(\mathrm{O}-\mathrm{H})\left(1639 \mathrm{~cm}^{-1}\right)$ vibration bands versus time, from 0 to $24 \mathrm{~h}$ of JNP in vitro (blue), untreated skin (red) and skin+JNP (green).

Figure 4 : Evolution of intensity ratios of $v(\mathrm{C}=\mathrm{O})\left(1739 \mathrm{~cm}^{-1}\right)$ and $\delta(\mathrm{O}-\mathrm{H})\left(1639 \mathrm{~cm}^{-1}\right)$ vibration bands versus time of $\mathrm{JNP}$ at $22^{\circ} \mathrm{C}$ and $32^{\circ} \mathrm{C}$.

Figure 5 : Evolution of wavenumber of $v(\mathrm{C}=\mathrm{O})$ of lipids of skin, JNP and after cutaneous application of JNP and L.

Figure 6 : Evolution of wavenumber of $\delta(\mathrm{O}-\mathrm{H})$ of water of JNP before and after cutaneous application, $v(\mathrm{C}=\mathrm{O})$ of the keratin of skin and $v(\mathrm{C}=\mathrm{C})$ of Labrafil of skin $+\mathrm{L}$. 

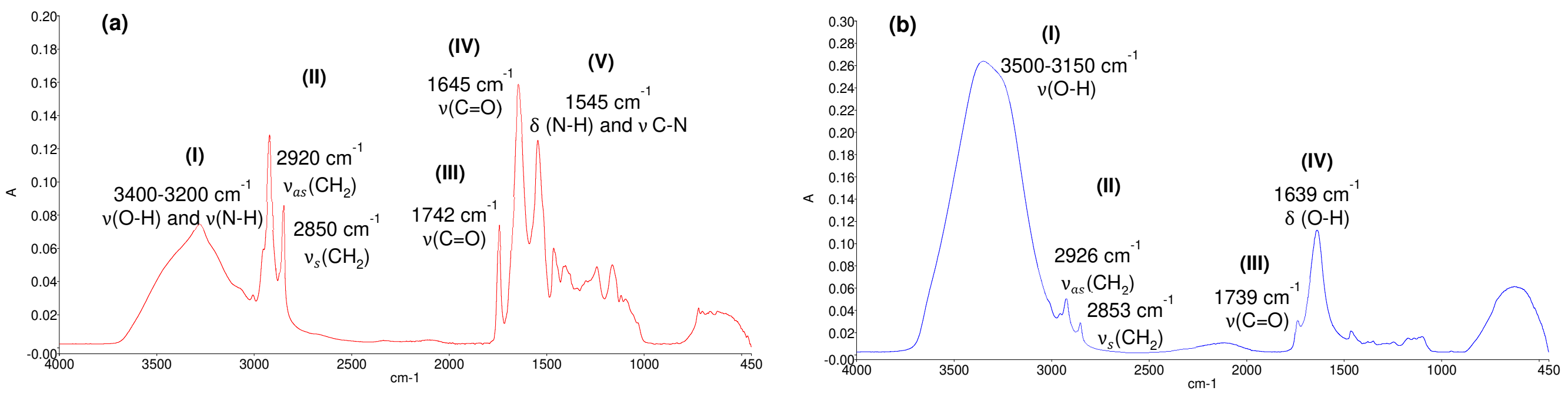

(c)

(II)

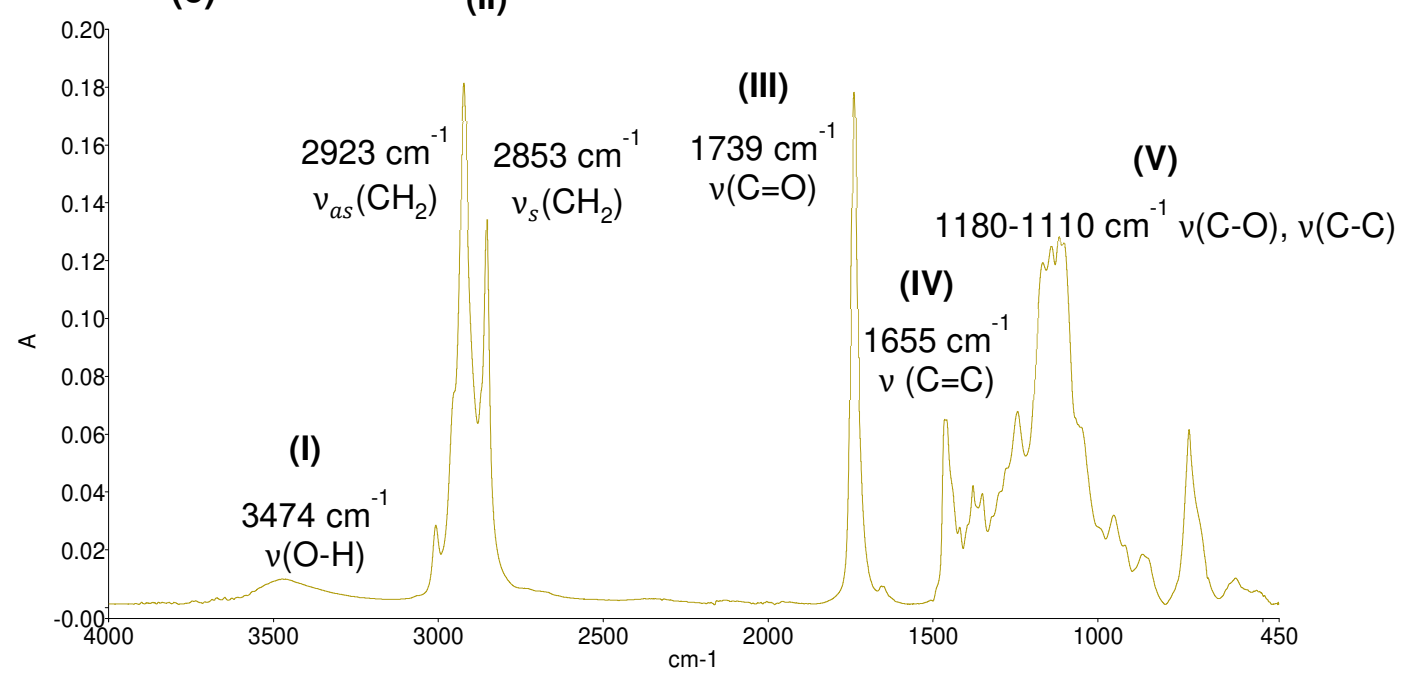


(a)

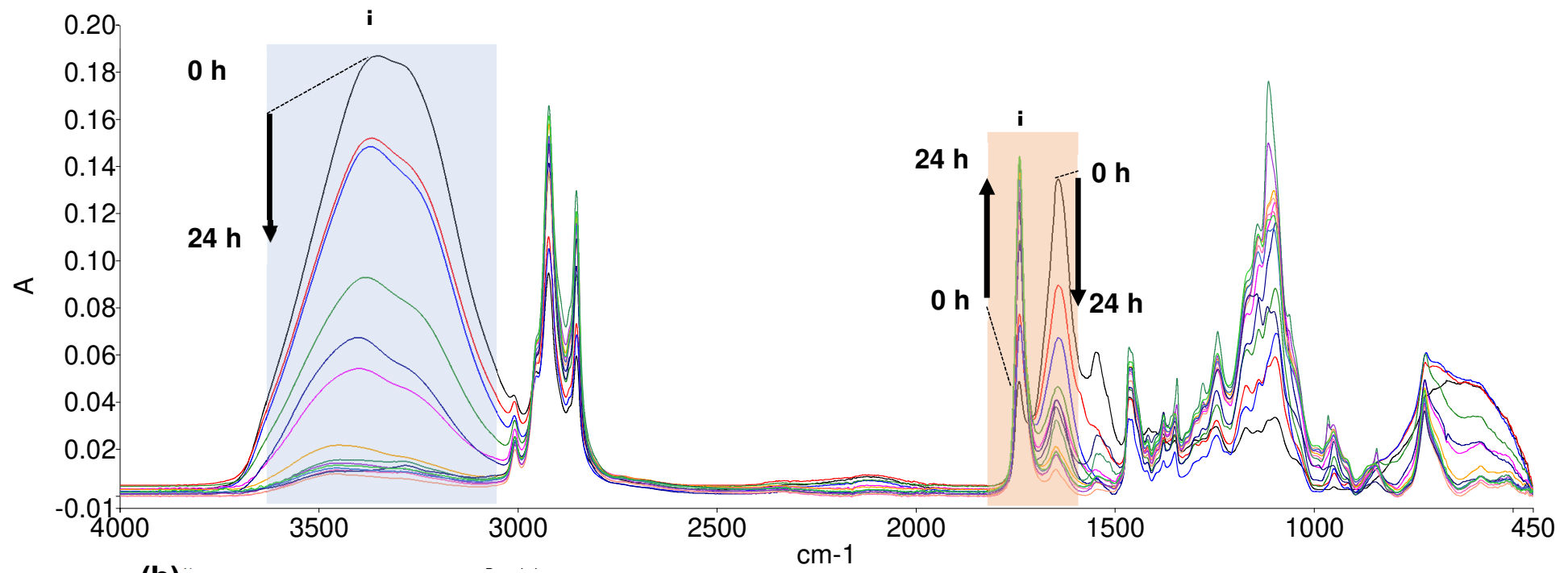

(b)

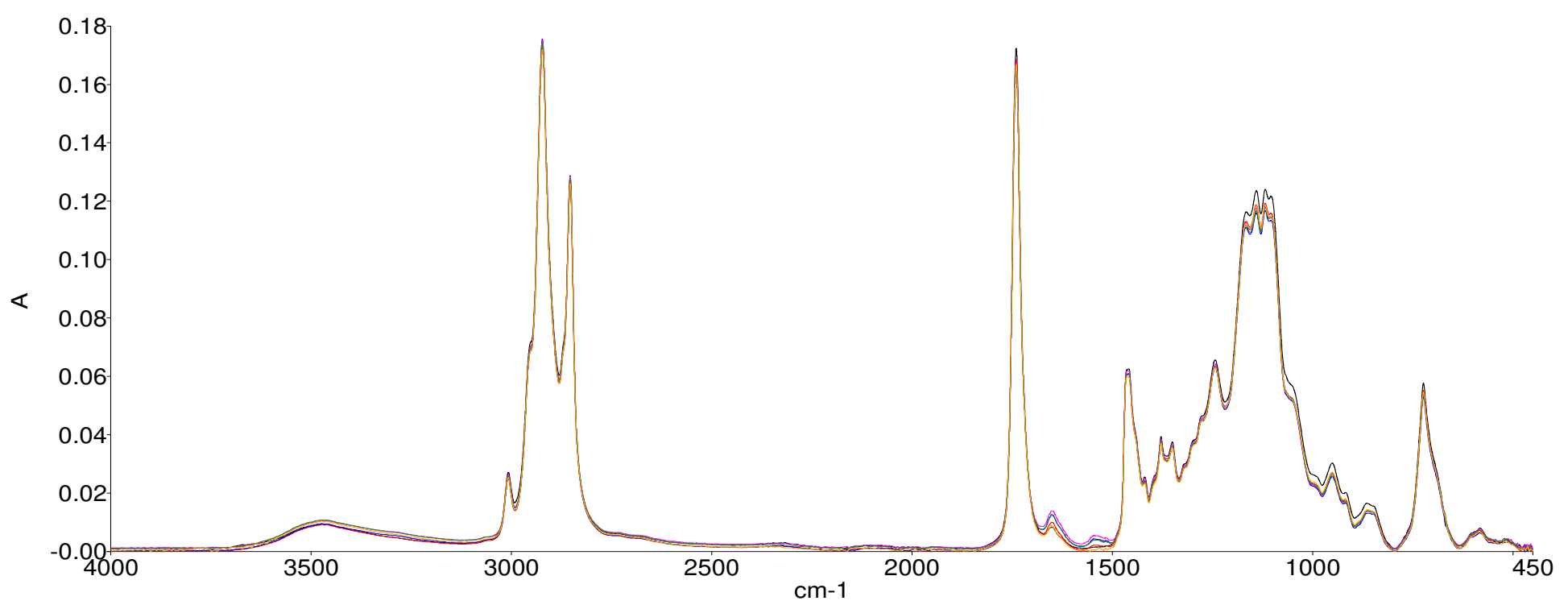




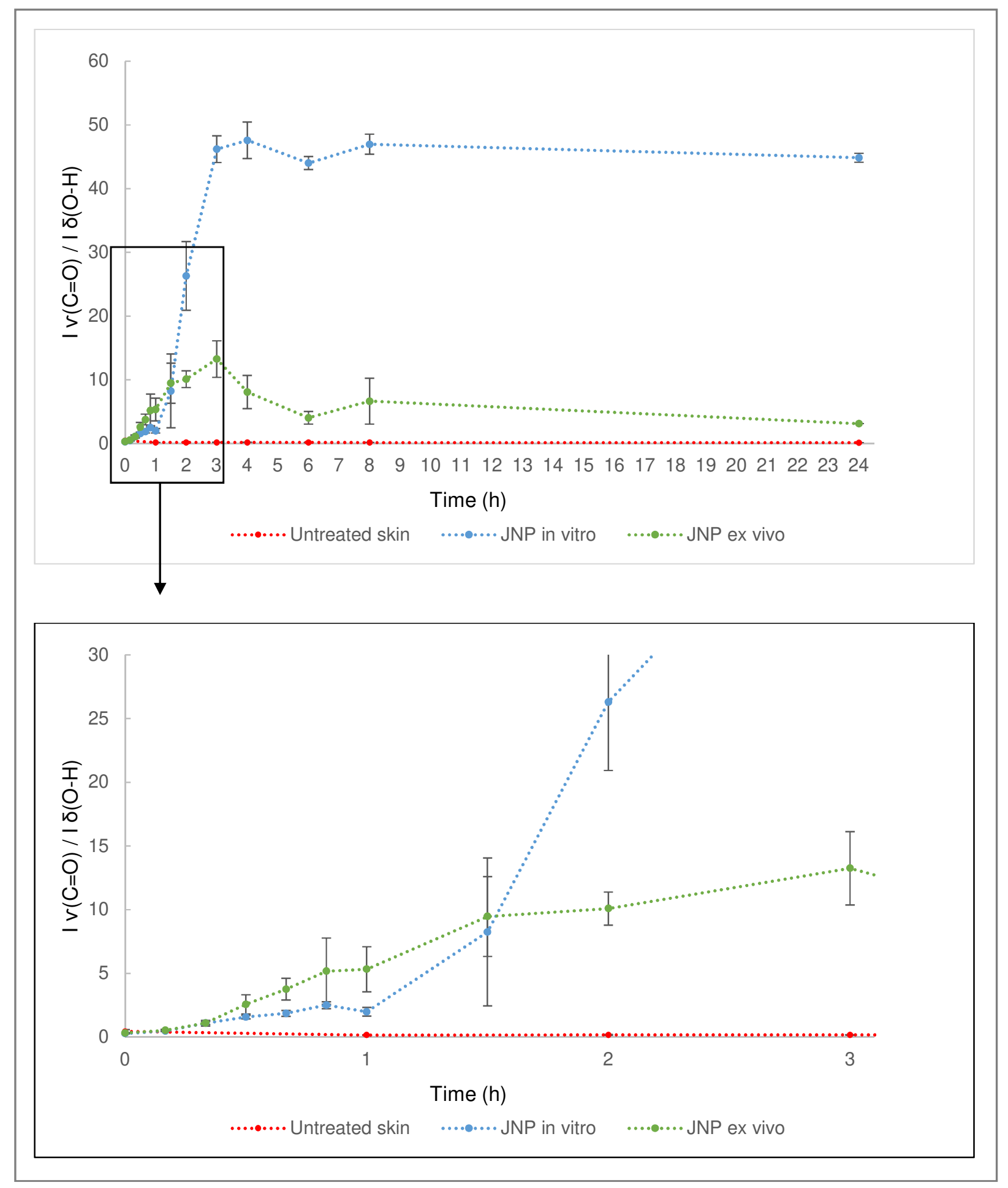




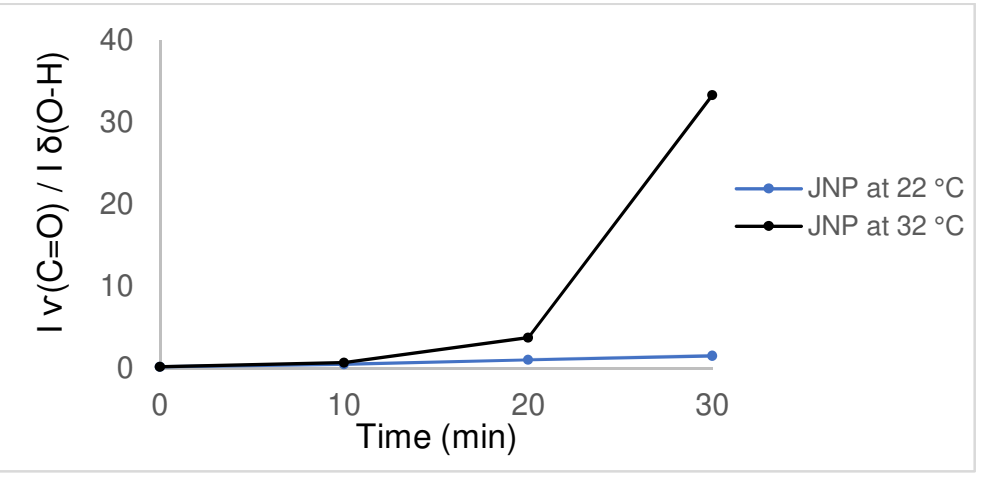




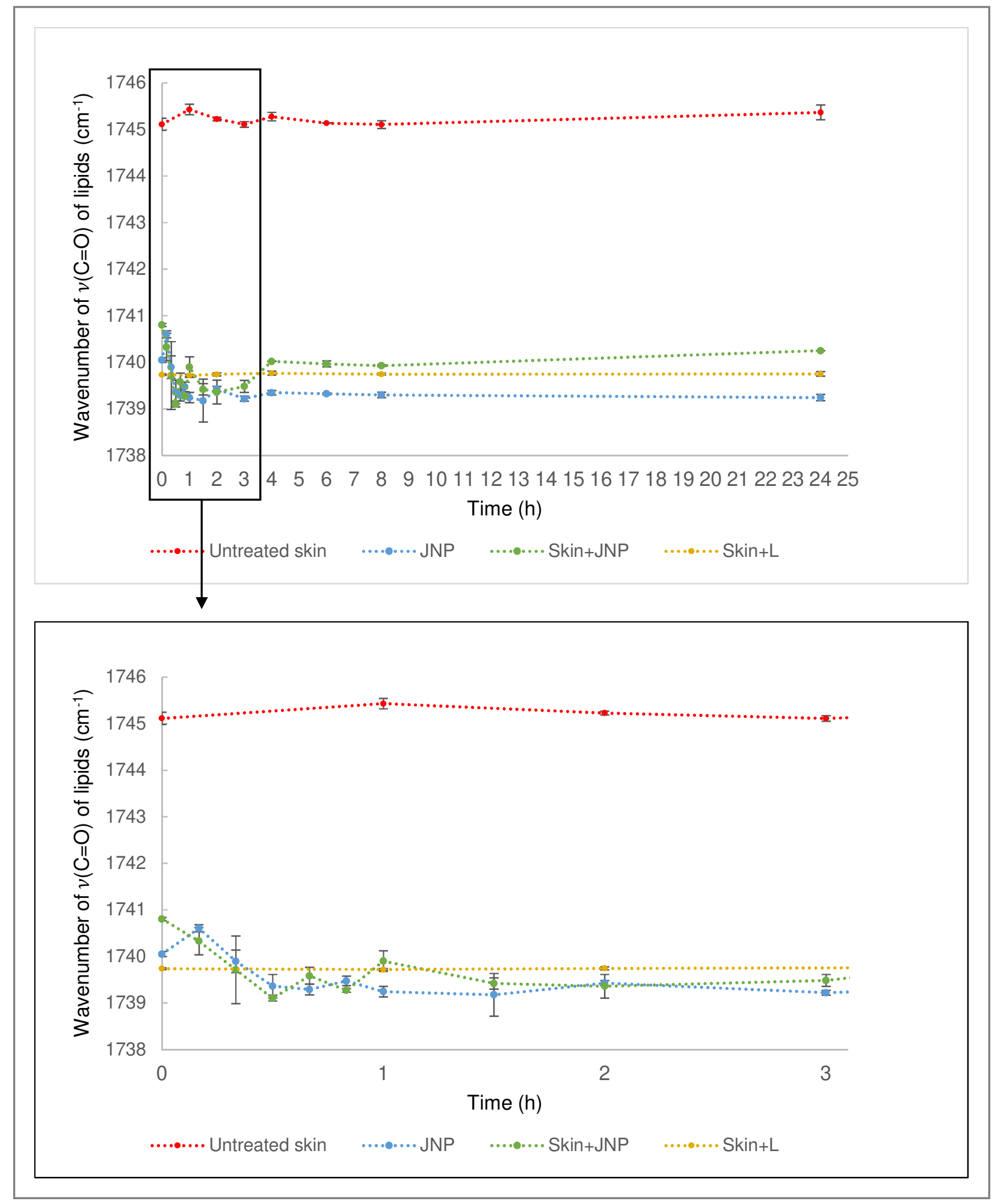




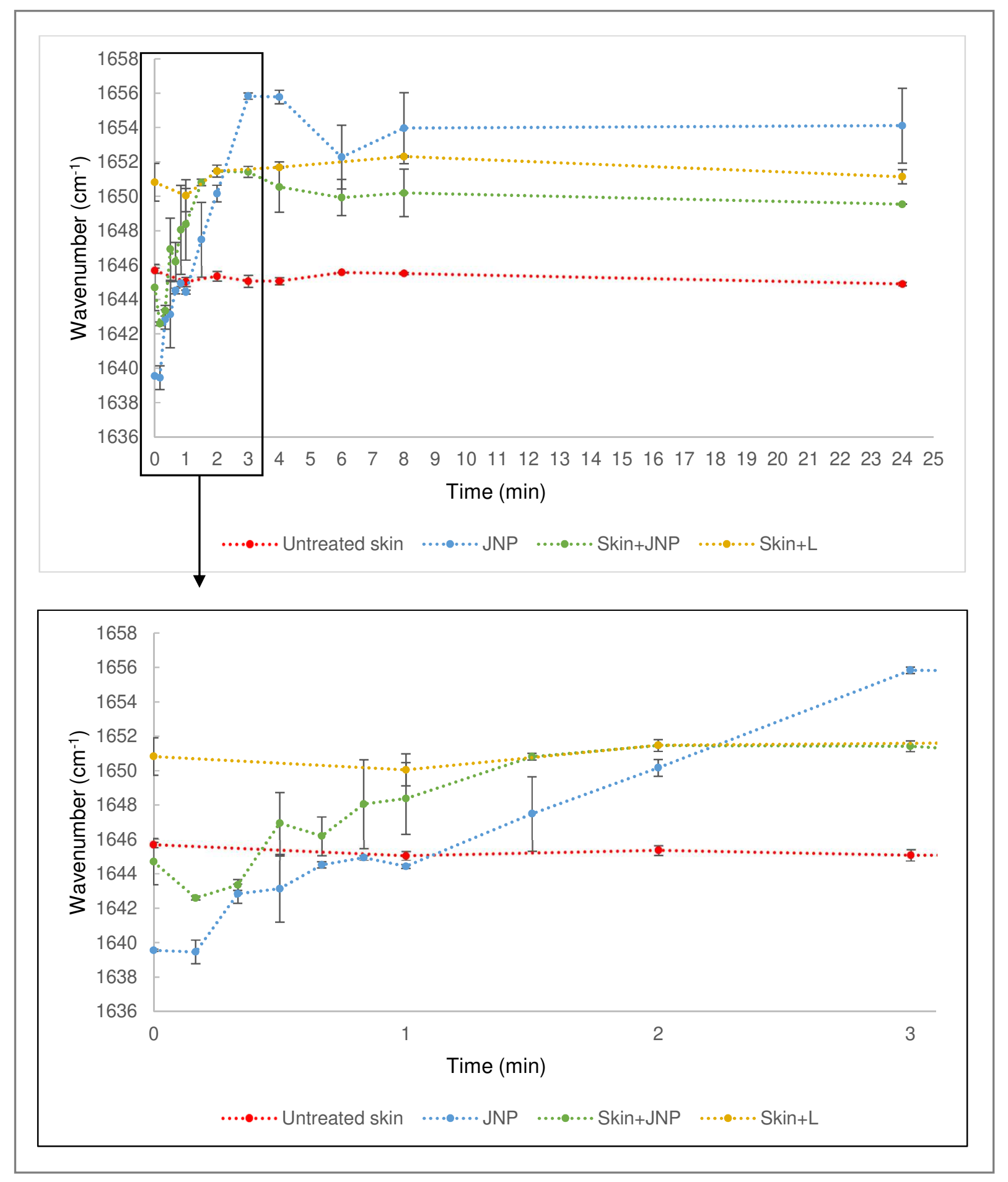

